\title{
Acute Pancreatitis in a Patient with Pancreas Divisium and Polycystic Kidney Disease
}

Cátia Pereira*, Amílcar Silva

Centro Hospitalar Universitário de Coimbra, Praceta, R. Prof. Mota Pinto, 3004-561 Coimbra, Portugal

\begin{tabular}{|c|c|}
\hline DOI: $10.36348 / \mathrm{sb} .2020 . v 06 \mathrm{i01} .001$ & | Received: 24.12 .2019 | Accepted: 04.01 .2020 | Published: 13.01 .2020 \\
\hline \multicolumn{2}{|l|}{ *Corresponding author: Cátia Pereira } \\
\hline $\begin{array}{l}\text { Copyright @ 2020: This is an open-acce } \\
\text { use, distribution, and reproduction in any } \\
\text { are credited. }\end{array}$ & $\begin{array}{l}\text { e terms of the Creative Commons Attribution license which permits unrestricted } \\
1 \text { use (NonCommercial, or CC-BY-NC) provided the original author and source }\end{array}$ \\
\hline
\end{tabular}

\section{MEDICAL IMAGES}

The authors report a case of an 80-year-old man with a personal history of hypertension, diabetes mellitus, acute stroke without permanent sequelae and chronic kidney disease who presented to an emergency department with abdominal pain. Acute pancreatitis was confirmed by elevations in the amylase and lipase and he was hospitalized.
The etiology of acute pancreatitis is often difficult to determine. The patient had been studied with magnetic resonance (MR) imaging that revealed the existence of pancreas divisum, one pancreatic pseudocyst (Figure-1) and polycystic kidney disease (Figure-2).
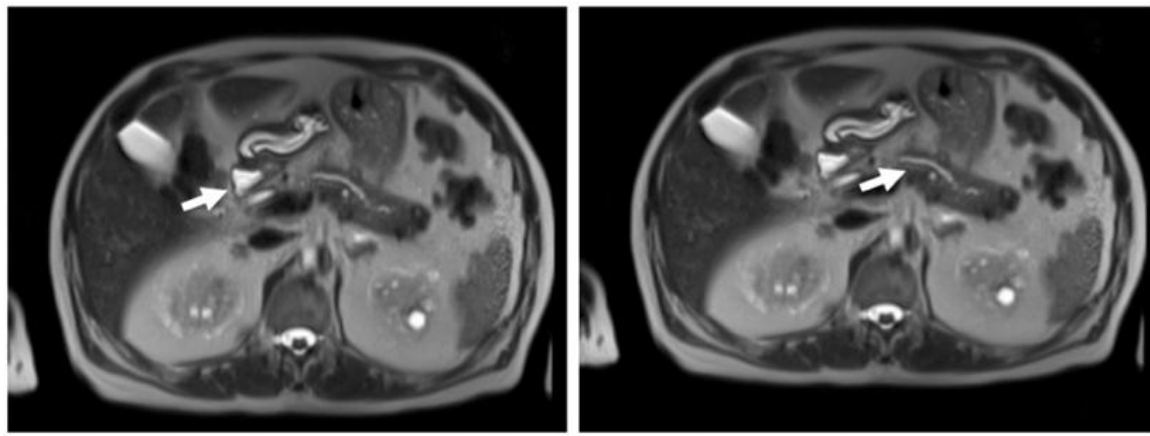

Fig-1: (A) Pancreatic cyst and (B) Pancreas divisum at MR Imaging sequences

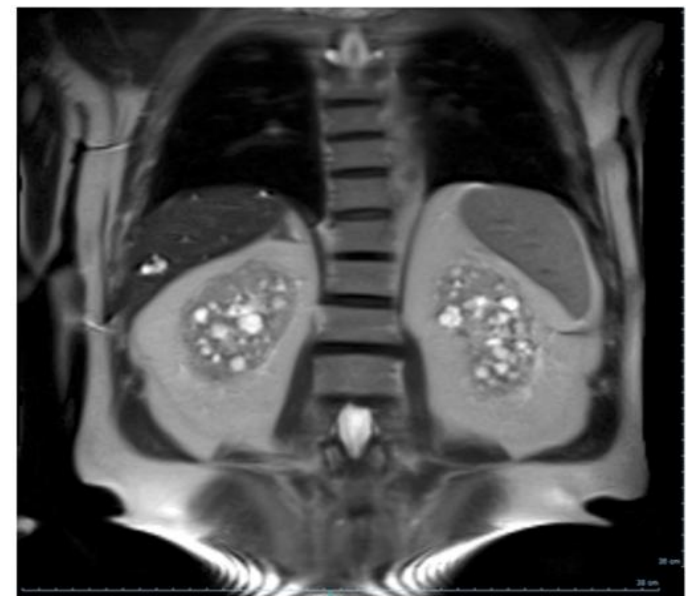

Fig-2: Policystic kidney disease 
The association between pancreatic cysts and polycystic kidney disease was described at the medical literature. Probably our patient had a PKD2 gene mutation but was not tested. On the other hand the divisum pancreas is a predisposing factor for acute pancreatitis. The authors highlight the tremendous importance of an exhaustive investigation about acute pancreatitis causes after the early disease manifestation.

\section{REFERENCES}

1. Bispo, M., Barreiro, P., Bana, T., Serra, D., Marques, P., Seves, I., ... \& Matos, L. (2010). Pâncreas Divisum no Lado Oculto da Pancreatite Aguda Recorrente: um Desafio Diagnóstico e Terapêutico. Jornal Português de Gastrenterologia, 17(1), 18-22.

2. Chen, H. J., Wang, J. J., Tsay, W. I., Her, S. H., Lin, C. H., \& Chien, C. C. (2017). Epidemiology and outcome of acute pancreatitis in end-stage renal disease dialysis patients: a 10-year national cohort study. Nephrology Dialysis Transplantation, 32(10), 1731-1736.

3. Golay, V., \& Roychowdhary, A. (2012). Acute pancreatitis in chronic kidney disease - a common but often misunderstood combination. Renal failure, 34(10), 1338-1340.

4. Kim, J. A., Blumenfeld, J. D., Chhabra, S., Dutruel, S. P., Thimmappa, N. D., Bobb, W. O., ... \& Prince, M. R. (2016). Pancreatic cysts in autosomal dominant polycystic kidney disease: prevalence and association with PKD2 gene mutations. Radiology, 280(3), 762-770.

5. Sastre López, A., Bernabéu Lafuente, M., \& Vanrell, Í. (2008). Acute pancreatitis and polycystic kidney disease. Nefrología (English Edition), 28(3), 352-353. 